\title{
CHEMICAL, PHYSICALL AND SENSORY PROPERTIES OF SWEET POTATO CAKE
}

\author{
SAMIHA, A. ALLOUSH \\ Experimental kitchen Research, Food Technology Research Institute, ARC, Giza- Egypt \\ (Manuscript received 16 December 2014)
}

\begin{abstract}
$\mathrm{S}$ weet potato has high nutritional value, not only its content of polysaccrides and minerals but also, its vitamin content of carotenes. Orange- fleshed sweet potato (OFSP) varieties rich in Beta-carotene, a precursor of vitamin $A$ is one of the least expensive sources of dietary vitamin A. Investigations on the use of sweet potato (Ipomea batata ) orange and white flour with wheat flour composite at various levels of substitution (10,20, and 30\%) in cake production were carried out. Sweet potato flour can serve as a source of energy and nutrients (carbohydrates, Beta-carotene, minerals ( $\mathrm{Ca}, \mathrm{K}, \mathrm{Fe}, \mathrm{P}$, and $\mathrm{Z})$, can add natural sweetness, color, flavor and dietary fiber to processed food products. All types of cakes were evaluated chemically, and physically. Total energy from cakes ranged from 404.9 -361.82 K.cal. The chemical composition showed that fresh sweet potato had lower protein content (4.51$2.96 \%)$ in orange and white verities respectively. Sensory evaluation results revealed that composite cake $(10 \%, 20 \%$ and $30 \%$ ) had no significant difference $(p>0.05)$ in taste At $30 \%$ level orange sweet potato was the best in volume increase, softness and overall acceptability. On the other hand, cohesiveness decreased with time, but increased with increased sweet potato flour in the cake. The shelf life of the produced cake increased for 30 days with cold storage.
\end{abstract}

\section{INTRODUCTION}

Sweet potato (Ipomea batatas L.) is very important vegetable crop food in many countries including Egypt. It is a member of the family Convolvulaceae, in which there are over 400 Ipomea species distributed throughout the tropics, but sweet potato is the only one of economic importance. Sweet potato is one among the two important crops: common beans and sweet potato, that help so much in the traditional foods of many countries. Beta-carotene-rich sweet potato (also known as orange - fleshed sweet potato) is one of a few new crops, which is both an excellent source of energy and important nutritive substances that can contribute to improve the nutrient status of the community (Burri, 2011).

The crop is promoted by various organizations in Sub-Saharan Africa through the Sweet potato Action for Security and Health in Africa (SASHA) and worldwide 
through the Sweet potato Initiative for Profit and Health (SPIH) (International Potato Center, 2009). Orange-fleshed sweet potatoes are an excellent source of betacarotene and Vitamin A. They also have anti-inflammatory health benefits, amble potassium, Vitamin $C_{\text {, Vitamin }} \mathrm{B}_{\mathbf{6}}$, riboflavin, copper, pantothenic acid and folic acid.

The Sweet potato is an economical and healthful food crop containing betacarotene and substantial amounts of ascorbic acid and minerals. It is a good source of fiber which plays a favorable role in reducing blood cholesterol level. Sweet potato also contains a significant quantity of the anti-oxidant nutrients $\beta$-carotene, vitamin $\mathrm{C}$ and vitamin E; thus, its consumption inhibits the formation of free-radicals which have been implicated in the development of coronary heart disease (Woolfe, 1992). Both $\beta$ carotene and vitamin $\mathrm{C}$ are very powerful antioxidants that work in the body to eliminate free radicals. Free radicals are chemicals that damage cells and cell membranes and are associated with the development of conditions like other sclerosis, diabetic heart disease, and colon cancer. In addition, sweet potatoes are a good source of vitamin $B_{6}$, which is needed to convert homocysteine, an interim product created during an important chemical process in cells called methylation, into other benign molecules and this helps to reduce the risk of stroke or heart attack (Lorna, 2009).

Sweet potato flour can easily be promoted as a substitute for wheat flour in sweet baked products and can also be used for its high carotenoid content. However, the price of the sweet potato flour must be competitive with wheat flour and be good quality. This article defines and describes the different quality characteristics of sweet potato flour.Flour from sweet potato can be made when prices are low early in the season and may be stored for the future. Identifying and breeding the varieties that will be suitable for different end products will enhance the production of sweet potato.(Okorie, and Onyeneke 2012).

Cakes have enjoyed a relatively constant place in our diet for a long time and its continuous popularity has encouraged the development of newer and more attractive products that are available in the market today. It is often a dessert of choice for meals at ceremonial occasions, particularly wedding anniversaries and birthdays (Eke et. al., 2008).

Sweet potato flour can serve as a source of energy and nutrients (carbohydrate, $\beta$-carotene, pro vitamin $A$ ), minerals ( $\mathrm{Ca}, \mathrm{P}, \mathrm{Fe}, \mathrm{K}$, and $\mathrm{Z}$ ) and can add natural sweetness, color, flavor and dietary fiber to processed food products.

An efficacy study in South Africa demonstrated that consumption of $125 \mathrm{~g}$ of OFSP improved the vitamin A status of children, and could play a significant role in 
developing countries as a viable long-term food-based strategy for controlling vitamin A deficiency (Van Jaarsveld, et. al.,2005).

However, for sweet potato to be incorporated in the bakery products, processors have to be sure that consumers will either prefer the new products or be indifferent between them and the regular ones made purely from wheat flour. It is also important to ensure that sweet potato-wheat based products have appropriates characteristics of appearance, aroma, taste and texture, which are key determinants of consumers' sensory acceptability of bakery products. Other sensory tests of Cake products have found that replacing some basic components changes structure and volume of the crumb (Gujral and Rosell, 2004), and also structure and texture . Sweet potato flour was used as an antioxidant .Its effect could be attributed to the phenolic compounds and also to the presence of phospholipids that helped to belong the shelf life of storage.

The present study to utilize sweet potato for improving some bakery products which could be analyzed for physic- chemical, characteristics. Addition of various proportion of sweet potato flour in wheat flour can increase the nutritive values in terms of fiber and carotenoids.

The current work is aiming to utilize sweet potato flour in the improvement of bakery products as well as enhance both nutritive value and to extend the shelf- life of the product.

The current study aimed at producing and evaluating the quality properties of cake made the composite of wheat and sweet potato flours as a strategy to improve sweet potato utilization and improvement of smallholder income and livelihood. This investigation as undertaken to study the effect of adding sweet potato flour (orange and white) to wheat flour on some physical properties of the dough as well as on the characteristics of cake prepared there from. The object was to find the maximum proportion which could be used without lowering cake quality below an acceptable level. (Singh et. al., 2008).

\section{MATERIALS AND METHODS}

\section{Materials}

The Sweet potato varieties (white and orange) were obtained from local market in Giza, Egypt: wheat flour (72\% extraction rate), sugar, vanilla, batter, eggs, salt, baking powder and powdered milk were obtained from local market at Giza Egypt. 


\section{Methods}

\section{Production of Sweet Potato Flour}

The fresh sweet potatoes (Ipomoea batatas) were thoroughly washed to remove dirt and soil. They were peeled, washed, blanched with $0.25 \%$ of sodium metabisulphite solution for 15 mins, cut into slices and dried in a Gallenkamp hotbox oven at $70^{\circ} \mathrm{C}$ for 18 hours. Dried sweet potato chips were milled into flour (Eke and Kabari, 2010). Flour obtained was sieved through a $60 \mathrm{~mm}$ mesh sieve to obtain flour of uniform particle size. The flour was then packed in an air tight container for future use flour.

\section{Preparation of Cake:}

Cake formulas used in this study were in accordance to (A.A.C.C.1983) with some modification. The formulas are shown in table (1). For making cake, dried ingredients were combined except sugar. The sugar was added to the batter and beaten for $3 \mathrm{~min}$. Eggs were beaten and vanilla was added to the beaten eggs then water, egg-vanilla mixture was added gradually to the mixture and creaming for 2 min. The wheat flour was added to the last mixture gradually Six additions (100\%wheat) control sample and $10 \%, 20 \%, 30 \%$ substitution with sweet potato flour( orange and white variety) were made over a period of 7 mints with good creaming between the additions. This was done to prevent the curdling of batter. After batter development of a soft. The mixed batter, each at $(80 \mathrm{~g})$ were mixed with milk and water to proportion and poured into greased cake. These were put in the oven and baked at temperature of $180 \mathrm{C}^{\circ}$ for 20-25 mins. The cakes were cooled and removed from the pan after $1 \mathrm{hr}$. The cooled cake, were packaged in aluminum foils and kept in shelf until analysis.

Table 1. Formula of cake.

\begin{tabular}{|c|c|c|c|c|c|c|c|}
\hline $\begin{array}{c}\text { Ingredients } \\
(\mathrm{gm})\end{array}$ & \multicolumn{6}{|c|}{ Type of Cake } \\
\hline & Control & $\begin{array}{c}\text { White } \\
\text { sweet } \\
\text { potato } \\
\text { flour10\% }\end{array}$ & $\begin{array}{c}\text { white } \\
\text { Sweet } \\
\text { potato } \\
\text { flour } \\
20 \%\end{array}$ & $\begin{array}{c}\text { White } \\
\text { sweet } \\
\text { potato } \\
\text { flour } \\
30 \%\end{array}$ & $\begin{array}{c}\text { Orange } \\
\text { sweet } \\
\text { Potato } \\
\text { flour } 10 \%\end{array}$ & $\begin{array}{c}\text { Orange } \\
\text { Potato } \\
\text { flour } 20 \%\end{array}$ & $\begin{array}{c}\text { Orange } \\
\text { Potato } \\
\text { flour 30\% }\end{array}$ \\
\hline Wheat flour & 100 & 90 & 80 & 70 & 90 & 80 & 70 \\
\hline $\begin{array}{c}\text { Baking } \\
\text { powder }\end{array}$ & 10 & 10 & 10 & 10 & 10 & 10 & 10 \\
\hline Salt & 0.2 & 0.2 & 0.2 & 0.2 & 0.2 & 0.2 & 0.2 \\
\hline Sugar & 70 & 70 & 70 & 70 & 70 & 70 & 70 \\
\hline Better & 40 & 40 & 40 & 40 & 40 & 40 & 40 \\
\hline $\begin{array}{c}\text { Fresh egg } \\
\text { white }\end{array}$ & 75 & 75 & 75 & 75 & 75 & 75 & 75 \\
\hline $\begin{array}{c}\text { Dry skim } \\
\text { milk }\end{array}$ & 12 & 12 & 12 & 12 & 12 & 12 & 12 \\
\hline Water & 35 & 35 & 35 & 35 & 35 & 35 & 35 \\
\hline Vanilla & 0.75 & 0.75 & 0.75 & 0.75 & 0.75 & 0.75 & 0.75 \\
\hline
\end{tabular}




\section{Physical properties of cake samples}

Height, weigh, volume and specific volume were measured as mentioned by A.A.C.C (1983).

\section{Texture profile analysis}

Crud texture was determined by a machine (Cometech, B type, Taiwan).Provided with software. An Aluminum $40 \mathrm{~mm}$ diameter cylindrical probe was used in a "Texture profile Analysis" (TPA) double compression test to penetrate to $50 \%$ depth, at $1 \mathrm{~mm}$ Is speed test. Firmness $(\mathrm{N})$, gumminess $(\mathrm{N})$, chewiness $(\mathrm{N})$, adhesiveness (N.s), cohesiveness, springiness and resilience were calculated from the TPA graphic. Both, springiness and resilience were calculated from the TPA graphic. Both, springiness and resilience, give information about the after stress recovery capacity. But, while the former refers to retarded recovery, the latter concerns instantaneous recovery (immediately after the first compression, while the probe goes up. Texture determinations were carried out, after removing the crust, in (40*40*30) mm-sized samples by Bourne, M (2002).

\section{Chemical analysis}

The chemical analysis of the composite flours Moisture, protein, ash, fiber content and fat were determined to the methods described by A.O.A.C (2005).

Total carbohydrates were calculated by difference (100 - [protein + fat + ash]). Minerals were determined using atomic absorption according to A.A.C.C (1983). Vitamins and B-carotene were analyzed as outlined in Official Method of Analysis of A.O.A.C. International (2005).

\section{Sensory Evaluation of cakes:}

Cakes were judged for cells (uniformity, size of cells and thickness of walls), grain, texture (moistness, tenderness and softness), crumb color, (taste and flavor) and overall score by 10 panelists as described in A.A.C.C (1983). The panelists were chosen from the staff of Experimental kitchen Res. Dept., Food Tech. Research Institute, to evaluate cake organoleptic characteristics. Cake samples were left to cool $\left(32^{\circ} \mathrm{C}\right)$ for $4 \mathrm{hr}$. after backing then cake was cut and subjected to taste panel. The resulted data were statistically analyzed by analysis of variance using the General Linear Model (GLM) procedure within statistical analysis system. (SAS,1987).

\section{Storage of cake}

The cakes process were cooled and removed from the pan after $1 \mathrm{hr}$. The cooled cake, were packaged in aluminum foils and kept at $-18 \mathrm{C}^{\circ}$ to 30 days until analysis every 15 days to determined shelf life of cake. 


\section{Statistical Analysis}

The ores obtained were evaluated using the analysis of variance (ANOVA) method to determine the difference among the samples. The deviation of the scores from the mean was added and the mean.

\section{RESULTS AND DISCUSSION}

The chemical composition of fresh Sweet potato white and orange, wheat flour and sweet potato flour is presented in table (2). Moisture content of fresh sweet potato was (79 $-77.41 \%)$ in orange and white varieties. This was reduced during conventional drying by (17 and 15\%) in orange and white sweet potato flours respectively. The crude protein of wheat flour was $8.96 \%$, its carbohydrate and moisture were $70.84 \%$ and $8.65 \%$ respectively. But the protein content of fresh sweet potato $(4.51,2.96 \%)$ in orange and white varieties. Ash and crude fiber were (3.65, $3.41 \%)$ and $(2.82,5.21 \%)$ on orange and white fresh sweet potato respectively. These results are comparable to the result reported by Abdel-Magied et. al.(1992) who found that the protein content of fresh sweet potato ranged from 1.3 to $10 \%$. Values for fat, ash, total carbohydrates and energy ranged between $(0-0.43),(1.56-$ $5.03 \%),(83.56-90.29)$, and (382-394 K.cal) respectively. Table (2) obtained that fat content of fresh sweet potato were $(1.6-0.7 \%)$ on orange and white sweet potato respectively this results agreement with Navas et. al . (1999). They also reviewed that sweet potato has frequently been mentioned as a source of energy in the diet in cases where it invariably forms the major staple or more often when replaces wheat in times of their scarcity or high price. The result of proximate analysis of orange sweet potato flour indicated that it contained $68.92 \%$ carbohydrate, $5.32 \%$ crude protein, ether extract $2.10 \%$ ash and $0.80 \%$ crude fiber but the protein content of white sweet potato flour $2.9 \%$,other extract $3 \%$ ash and $4.89 \%$ crud fiber and carbohydrate level $73.71 \%$. The high level of carbohydrates is desirable in cake products because on heating starch granules in the presence of water, it swells and forms a gel which is important for the characteristic textures and structures of baked goods from the $10 \%$ dilution of the potato flour with the least in $50 \%$ dilution. This could be an indication that the occurrence of oxidative. Generally, there was decreased in protein, ether extract, moisture content and crude fiber contents of the composite flour as the level of substitution with potato flour increased.The sweet potato flour had less oil content and increase in ash and carbohydrate contents were observed as the substitution level also increased composition of cakes. 
Table 2. comparison of selected nutrients content in fresh, and processed flours from Wheat and sweet potato varieties

\begin{tabular}{|c|c|c|c|c|c|}
\hline Nutrient \% & FOSP & FWSP & OSPF & WSPF & WF \\
\hline Moisture & 79.0 & 77.41 & 17.0 & 15.0 & 8.65 \\
\hline Protein & 4.51 & 2.96 & 5.32 & 2.90 & 8.96 \\
\hline Fat & 1.61 & 0.70 & 2.10 & 0.80 & 1.69 \\
\hline Fiber & 0.80 & 5.21 & 3.5 & 4.89 & 0.72 \\
\hline Ash & 3.65 & 2.82 & 2.10 & 3.00 & 0.41 \\
\hline Carbohydrate & 11.23 & 10.99 & 68.92 & 73.71 & 70.84 \\
\hline
\end{tabular}

Fresh Orange Sweet Potato (FOSP); Fresh white Sweet Potato (FWSP); White Sweet Potato Flour (WSPF); Orange Sweet Potato Flour (OSPF) and Wheat Flour (WF)

The result of the analysis of cake made from wheat flour and sweet potato flour (white and Orange) blends are shown in Table (3). There was an increase in moisture, fat and ash contents of the composite cake other level of potato flour substitution increased. There was however, a decrease in the protein, crude fiber and carbohydrate content of the composite cakes. This may be due to heat employed which led to destruction of nutrients due to high temperature and duration of heating of the batter (Erdman, and Erdman, 1982)The moisture content of the wheat cake was lower $(24.84 \%)$ than those diluted with white sweet potato flour $(26.01 \%$, $26.43 \%, 26.54 \%)$ and orange sweet potato flour (27.11 $-27.32 \%$ and $27.13 \%$ ) respectively. This moisture content of the cake was below the values reported for several cakes this deviation may be attributed to method and recipe used. There was virtually no detectable crude fiber in the cake samples. This may be due to dilution occasioned by the dilution of fat which resulted in the quantity of fiber left which was minute. Though fiber has been reported to have no nodal value added to human foods, they add bulk to the foods and aids in bowl movement. Protein content of the composite flours reduced with increasing substitution with sweet potato flour level. 
Table 3. Effect of adding different levels of sweet potato flour on chemical composition of prepared cake.

\begin{tabular}{|c|c|c|c|c|c|c|c|}
\hline Type of Cake & $\begin{array}{c}\text { Moisture } \\
(\%)\end{array}$ & $\begin{array}{c}\text { Protein } \\
(\%)\end{array}$ & $\begin{array}{c}\text { Fat } \\
(\%)\end{array}$ & $\begin{array}{c}\text { Fiber } \\
(\%)\end{array}$ & $\begin{array}{c}\text { Ash } \\
(\%)\end{array}$ & $\begin{array}{c}\text { Carbohydrate } \\
(\%)\end{array}$ & $\begin{array}{c}\text { Energy } \\
(\mathrm{K} . \mathrm{Cal})\end{array}$ \\
\hline Control WF & 21.84 & 8.68 & 21.9 & 0.66 & 3.65 & 43.27 & 404.90 \\
\hline WSPF 10\% & 23.01 & 7.30 & 20.11 & 0.83 & 3.43 & 43.67 & 384.87 \\
\hline WSPF 20\% & 22.43 & 6.88 & 20.41 & 0.74 & 3.62 & 41.92 & 378.89 \\
\hline W SPF 30\% & 23.54 & 6.65 & 15.71 & 0.67 & 3.52 & 42.91 & 375.63 \\
\hline OSPF 10\% & 27.11 & 6.22 & 14.00 & 0.65 & 3.89 & 42.13 & 363.40 \\
\hline OSPF 20\% & 27.32 & 5.73 & 16.22 & 0.96 & 3.72 & 41.05 & 337.10 \\
\hline OSPF 30\% & 28.13 & 4.52 & 16.62 & 0.79 & 3.90 & 40.04 & 327.82 \\
\hline
\end{tabular}

White Sweet Potato Flour (WSPF) Orange Sweet Potato Flour (OSPF)

Wheat Flour (WF). Energy (K. Cal) $=4$ ( Carbohydrate + Protein $)+9$ Fat

\section{Vitamins and Minerals}

The results from the test of significance (Table 4) for the fresh, orange and white sweet potatoes flour showed that the orange sweet potato was a high content in the ßeta carotene $(9.14 \%)$ but the white sweet potato has less $(1.02 \%)$ and the orange sweet potato flour has a higher percentage than white sweet potato flour. Studies have indicated that the vitamin $\mathrm{C}$ contents of fresh and flour white sweet potatoes were found to be $37 \mathrm{mg} / 100 \mathrm{~g}$ Kapinga et. al., (2007). The results obtained in this study showed that the vitamin $C$ was less than fresh and flour orange sweet potato $(27.75,25.23)$ and $(26.86,20.76)$ respectively. At the same table shows that mineral content of sweet potato varieties and flours proved to be a good source for some minerals such as $\mathrm{Ca}, \mathrm{P}, \mathrm{K}, \mathrm{Fe}$, and $\mathrm{Zn}$. the result obtained that the OSP was a higher percentage than WSP in the mean Ca content (111.5-115.4) mg $/ 100 \mathrm{~g}$. They were also no significantly different from the content of iron on the OSPF and WSPF (3.203 2.096).the potassium content were $(149.26$ - 126.87) on OSP and WSP respectively. 
Table 4. Vitamins and Minerals content of fresh and processed flours from Wheat and sweet potato varieties

\begin{tabular}{|c|c|c|c|c|c|}
\hline $\begin{array}{c}\text { Vitamins } \\
\text { Mg/100gm }\end{array}$ & Fresh OSP & Fresh WSP & OSPF & WSPF & WF \\
\hline ßeta-carotene & 9.14 & 1.020 & 8.07 & 0.32 & -- \\
\hline Vitamin-C & 27.75 & 25.23 & 26.86 & 20.76 & .85 \\
\hline Minerals \\
mg/1oo gm
\end{tabular}

White Sweet Potato Flour (WSPF); Orange Sweet Potato Flour (OSPF) wheat Flour (WF)

\section{Sensory Evaluation}

Table (5)show the sensory evaluation result of the Wheat cake 100\% (control sample) and Sweet potato cake as a different level (10, 20 and 30\%) from sweet potato (orange and white) The purpose of the current study is to apply the sensory profiling method involving a panel of subjects in order to identify the sensory attributes that best characterize the properties of appearance, taste, flavor, and texture profile analysis of 'control sample' wheat flour only products and other products with a percentage of wheat flour replaced with sweet potato flour. Singh et. al.(2008) assessed the textural and sensory properties of cake supplementing various proportions of sweet potato flour (10-20-30 \%) and wheat flour. The cake samples were evaluated by a panel of 10 members. The panel evaluated the following sensory attribute ,texture/ Appearance /color by-(8.8-9) and 9.- 9.40 for cake while taste score ranged from 8.8 - 9 in cake whish add $30 \%$ orang sweet potato flour but the sample cake which added $30 \%$ white sweet potato flour having the lowest score(7.47.9) and sample (orang sweet potato $20 \%$ ) having the highest score. Color values ranged from $(8.5-7.6)$ in samples of cake which added $30 \%$ white sweet potato flour with having the lowest score. and the highest score of color on the samples which added orang sweet potato. General acceptability values ranged from 8 - 9.4 in samples of cake substitution of wheat flour with sweet potato up to $30 \%$ (flour basis) indicated that cakes baked with composite wheat flour improved their sensory attributes. For substitution levels of $20 \%$ orange and white-sweet potato flour, attribute like taste $\&$ flavor, texture and general acceptability showed no significant 
difference $(P \geq 0.05)$ and in other levels in cake. There were no significant differences $(P \geq 0.05)$ in color Substitution levels of up to $20 \%$ and $30 \%$ were generally acceptable in cake samples. The level of ingredients of cake samples recipes preparation have been reported to affect the sensory attributes, preference and overall acceptability of the cakes (Dansby and Bouell- Benjamin., 2003).

Table 5. Effect of adding different levels of sweet potato flour on Sensory evaluation of prepared cake.

\begin{tabular}{|r|c|c|c|c|c|}
\hline Type of Cake & Color & Texture & Taste & Odor & $\begin{array}{c}\text { Overall } \\
\text { acceptability }\end{array}$ \\
\hline Control WF & $8.5^{\mathrm{a}}$ & $8.8^{\mathrm{ab}}$ & $8.8^{\mathrm{a}}$ & $9.0^{\mathrm{a}}$ & $9.0^{\mathrm{a}}$ \\
\hline W PF 10\% & $8.2^{\mathrm{b}}$ & $7.6^{\mathrm{bc}}$ & $9.4^{\mathrm{a}}$ & $8.4^{\mathrm{a}}$ & $8.4^{\mathrm{b}}$ \\
\hline WSPF 20\% & $8^{\mathrm{b}}$ & $7.7^{\mathrm{bc}}$ & $8.0^{\mathrm{b}}$ & $8.4^{\mathrm{a}}$ & $8.3^{\mathrm{b}}$ \\
\hline WSPF 30\% & $7.9^{\mathrm{b}}$ & $7.9^{\mathrm{b}}$ & $7.9^{\mathrm{b}}$ & $8.2^{\mathrm{b}}$ & $8.0^{\mathrm{b}}$ \\
\hline OSPF 10\% & $8.2^{\mathrm{b}}$ & $8.3^{\mathrm{b}}$ & $8.2^{\mathrm{b}}$ & $8.0^{\mathrm{b}}$ & $8.2^{\mathrm{b}}$ \\
\hline OSPF 20\% & $8.5^{\mathrm{a}}$ & $8.4^{\mathrm{b}}$ & $8.2^{\mathrm{b}}$ & $8.0^{\mathrm{b}}$ & $8.1^{\mathrm{b}}$ \\
\hline OSPF 30\% & $8.4^{\mathrm{a}}$ & $9.0^{\mathrm{a}}$ & $9.0^{\mathrm{a}}$ & $7.9^{\mathrm{bc}}$ & $9.4^{\mathrm{a}}$ \\
\hline
\end{tabular}

White Sweet Potato Flour (WSPF); Orange Sweet Potato Flour (OSPF) Wheat Flour (WF )

\section{Physical properties of produced cakes:}

Physical properties of cakes like height, weight, volume and specific volume of produced cake were found in table (6) slight differences could be observed between control sample and those of other samples.Table (6) show that all samples of cake had higher moisture content it ranged from 26.01 to $28.13 \%$ than control (21.84\%). Such increase in moisture may be due to the levels of substituted fibers which absorb more water than starch. Also data in the same table show that height, volume and specific volume in all samples of cake increased by increasing sweet potato flour substitution from 10-30 \%. The highest increase of height, volume and specific volume was found in sample at level $30 \%$ WSPF recorded $6.4 \mathrm{~cm}, 110.42 \mathrm{~cm}^{3}$ and $2.54 \mathrm{Cm}^{3}-100 \mathrm{gm}$ for these parameters, respectively comparing with control sample which recorded $6.2 \mathrm{~cm}, 133.12 \mathrm{Cm} 3$ and $1.87 \mathrm{~cm} 3 / \mathrm{gm}$ for the same parameter respectively. The weights of cake samples increased by increasing sweet potato flour from $10-30 \%$ (Van, Hal, 2000). 
Table 6. Effect of adding different levels of sweet potato flour on Physical Properties of prepared cake.

\begin{tabular}{|c|c|c|c|c|}
\hline Type of Cake & Height(Cm) & Weight(gm) & $\begin{array}{c}\text { Volume } \\
\mathbf{( C m ) 3}\end{array}$ & $\begin{array}{r}\text { Specific Volume } \\
\text { Cm3 Igm }\end{array}$ \\
\hline Control & 5.12 & 71.09 & 133.12 & 1.87 \\
\hline WSPF 10\% & 5.32 & 76.08 & 138.32 & 1.81 \\
\hline WSPF 20\% & 5.33 & 62.21 & 138.58 & 2.23 \\
\hline WSPF 30\% & 5.40 & 55.21 & 140.40 & 2.54 \\
\hline OSPF 10\% & 5.42 & 78.10 & 140.92 & 1.80 \\
\hline OSPF 20\% & 5.04 & 63.32 & 131.04 & 2.07 \\
\hline OSPF 30\% & 5.22 & 74.14 & 135.77 & 1.83 \\
\hline
\end{tabular}

White Sweet Potato Flour (WSPF); Orange Sweet Potato Flour (OSPF)

\section{Texture Profile Analysis}

For instance, as shown in Table (7) hardness decreased gradually with increased levels of sweet potato flour, but the decrease at sample level $30 \%$ sweet potato flour replacement was relatively small. The same table, cake chewiness decreased slightly with increased sweet potato. Cohesiveness, generally increased slightly with increased levels of sweet potato. In a general trend, the overall effect of sweet potato at up to $20 \%$ replacement on the textural properties of reheated control sample, as compared to freshly prepared, was relatively small and insignificant. Chewiness, of type of cake increased significantly $(p<=0.05)$ up to $(1.287)$ at level $20 \%$ orang sweet potato flour addition, but at $30 \%$ sweet potato flour the values increased to 2.138 . The cohesiveness increased significantly from 0.571 to 0.729 up to $10 \%$ sweet potato flour addition and then decreased to 0.444 with increasing white sweet potato flour to $30 \%$ after storage 30 days. Table (6) shows the texture profile analysis of cake at (zero time, after 15 days and after 30 days). At zero time springiness increased at sample 30\% (OSPF) high percentage but increased significant at 20\% sweet potato flour addition. The cohesiveness increased significantly from 469 to 0.515 up to $10 \%$ sweet potato flour addition after 15 days and then decreased to (0.317) with increasing orang sweet potato flour $30 \%$, but chewiness decreased 2.152 to 0.364 when white sweet potato flour increased after storage at $18 \mathrm{c}^{\circ}$ after 15 days. Addition of sweet potato flour to wheat flour caused a decrease in extensibility of the cake. After 30 days of storage chewiness increased significantly from sample which addition orange sweet potato flour $30 \%(1.148$ to 1.907$)$ with increasing the proportion of sweet potato flour. The whit-orange color of sweet potato flour was caused by the presence of carotenoid pigments, which affect the red-green chromaticity. A similar trend was observed for the cake dough by level OSPF $30 \%$ (Bourne, M 2002). 
Table 7. Effect of adding different levels of sweet potato flour on Texture profile of cake samples

\begin{tabular}{|c|c|c|c|c|c|c|c|c|c|c|c|c|c|c|c|c|c|c|}
\hline \multirow[t]{2}{*}{ Items } & \multicolumn{3}{|c|}{ Firmness } & \multicolumn{3}{|c|}{ Cohesiveness } & \multicolumn{3}{|c|}{ Gumminess } & \multicolumn{3}{|c|}{ Chewiness } & \multicolumn{3}{|c|}{ Springiness } & \multicolumn{3}{|c|}{ Resilience } \\
\hline & $\begin{array}{l}\text { Zero } \\
\text { Time }\end{array}$ & $\begin{array}{c}15 \\
\text { days }\end{array}$ & $\begin{array}{r}30 \\
\text { days }\end{array}$ & $\begin{array}{l}\text { Zero } \\
\text { Time }\end{array}$ & $\begin{array}{l}15 \\
\text { days }\end{array}$ & $\begin{array}{c}30 \\
\text { days }\end{array}$ & $\begin{array}{l}\text { Zero } \\
\text { Time }\end{array}$ & $\begin{array}{c}15 \\
\text { days }\end{array}$ & $\begin{array}{r}30 \\
\text { days }\end{array}$ & $\begin{array}{l}\text { Zero } \\
\text { Time }\end{array}$ & $\begin{array}{c}15 \\
\text { days }\end{array}$ & $\begin{array}{c}30 \\
\text { days }\end{array}$ & $\begin{array}{l}\text { Zero } \\
\text { Time }\end{array}$ & $\begin{array}{c}15 \\
\text { days }\end{array}$ & $\begin{array}{l}30 \\
\text { Days }\end{array}$ & $\begin{array}{l}\text { Zero } \\
\text { Time }\end{array}$ & $\begin{array}{c}15 \\
\text { days }\end{array}$ & $\begin{array}{r}30 \\
\text { days }\end{array}$ \\
\hline Control & 4.610 & 6.280 & 6.470 & 0.578 & 0.398 & 6.470 & 1.307 & 2.501 & 3.694 & 0.892 & 1.002 & 2.723 & 0.682 & 0.401 & 0.737 & 0.310 & 0.207 & 0.352 \\
\hline $\begin{array}{l}\text { WSPF10 } \\
\%\end{array}$ & 4.810 & 10.49 & 5.150 & 0.729 & 0.230 & 3.240 & 2.631 & 1.424 & 1.716 & 1.906 & .434 & 1.853 & 0.725 & 0.305 & 0.622 & 0.558 & 0.141 & 0.262 \\
\hline $\begin{array}{l}\text { WSPF20 } \\
\%\end{array}$ & 5.050 & 5.000 & 6.080 & 0.615 & 0.264 & 5.150 & 3.505 & 2.769 & 2.504 & 2.849 & .839 & 1.653 & 0.813 & 0.303 & 0.660 & 0.446 & 0.141 & 0.437 \\
\hline $\begin{array}{l}\text { WSPF30 } \\
\%\end{array}$ & 3.480 & 6.080 & 5.150 & 0.525 & 0.229 & 6.080 & 3.104 & 1.143 & 2.702 & 2.152 & .364 & 1.727 & 0.693 & 0.318 & 0.646 & 0.322 & 0.086 & 0.364 \\
\hline $\begin{array}{l}\text { OSPF10 } \\
\%\end{array}$ & 2.790 & 6.720 & 6.080 & 0.469 & 0.300 & 5.150 & 1.826 & 1.825 & 2.522 & 1.287 & .713 & 1.662 & 0.705 & 0.391 & 0.659 & 0.764 & 0.124 & 0.444 \\
\hline $\begin{array}{l}\text { OSPF20 } \\
\%\end{array}$ & 3.430 & 7.600 & 3.820 & 0.557 & 0.303 & 6.080 & 1.309 & 2.039 & 3.254 & 1.794 & .672 & 2.103 & 0.606 & 0.330 & 0.646 & 0.330 & 0.119 & 0.352 \\
\hline $\begin{array}{l}\text { OSPF30 } \\
\%\end{array}$ & 2.260 & 6.280 & 3.240 & 0.571 & 0.328 & 3.820 & 1.910 & 2.492 & 2.081 & 2.138 & 1.907 & 1.566 & 0.596 & 0.765 & 0.52 & 0.299 & 0.136 & 0.352 \\
\hline
\end{tabular}

White Sweet Potato Flour (WSPF); Orange Sweet Potato Flour (OSPF). 


\section{CONCLUSION}

The incorporation of sweet potato flour (white and orange) in the formulation of wheat cakes was found to improve the physicochemical properties of the product wheat- sweet potato cakes, at $10-20-30 \%$ sweet potato flour incorporation showed a flow behavior more like that of the traditional wheat batter and was more useful for cake preparation. Textural properties such as hardness, chewiness and cohesiveness were improved and became comparable with those of the wheat cake control. Protein content, dietary fiber, total carbohydrate and calories differed very little for all cakes. However, sweet potato cakes had substantially higher contents of ßeta-carotene, which can the dietary status in segments of the population that could be consume low amounts of ßeta-carotene in their diets.

\section{REFERENCES}

1. A.A.C.C. 1983. American Association of cereal chemists, Approved methods of A.A.C.C. published by American association of cereal chemists Innc., St.Poul, Mminnesota, USA

2. Abdel-Magied, M. M.,abdel- Hafez, A. and Wareed, A.W. 1992. Chemical and organoleptical evaluation of sweet potato candied products.Bull.Fac.of Agric.Univ.of Cairo 43:65-86.

3. A.O.A.C. 2005. Official Methods of Analysis $16^{\text {th }}$ Edition, Association of Official

4. Analytical Chemists, Washington DC.

5. Bourne, M. C. 2002. Food texture and viscosity; Concept and measurement. Elsevier 2 nd Ed ., PP 257-290,Academic press, LondonUK.

6. Burri BJ. 2011. Evaluating sweet potato as an intervention food to prevent vitamin A deficiency. Compr. Rev. Food Sci. Food Safety. 10: 118-130.mes in Human Nutrition, FAO; Rome pp12..

7. Dansby MA, Bovell-Benjamin AC. 2003. Sensory characterization of a eat sweet potato breakfast cereal by descriptive analysis. J. Food Sci., 68(2):706709.

8. Eke-Ejiofor, J. and Kiin-Kabari D (2010): Chemical pasting, functional and sensory properties of Sweet and Potato Chips. Nigeria Food Journal 28 (2), 47-48.

9. Erdman, J.W. and Erdman, E.A. 1982. Effect of home preparation practices nutritive value of foods in handbook of nutritive value of foods. Miloslaw Recheign, Florida 1: 237 -263. 
10. International Potato Center. 2009. Sweet potato Initiative for Profit and Health Brochure.http://www.cipotato.org/research/partnerships-and-specialprojects/sasha-program. Accessed 11 November 2011.technology 17(1):13-22.

11. Kapinga R, Tumwegamire $S$, and Ndunguru J. 2007. Status report of VITAA (Vitamin A for Africa): A partnership program combating Vitamin A deficiency through increased utilization of orange-fleshed sweetpotato in sub-Saharan Africa -VITAA, Uganda, pp. 37-38.

12. Lorna, F. 2009. Regulates Cardiovascular Development and Postnatal Function of Endothelium.Cell Adhesion and Migration, 3:143 - 145.

13. Navas, P.B.,Carrasquero,A. and Mantilla, J. 1999. Chemical characteristics of sweet potato(Ipomoea batatas) Var. Carolina flour. Revista de la Faculated-deAgronomia - Universidad-del-Zulia.

14. Okorie, S.U.and Onyeneke, E.N. 2012. Production And Quality evaluation of backed cake from blend of sweet potatoes and Wheat flour -Part-I: Natural \& Applied Sciences. Vol. 3, No. 2, 9944-9953.

15. SAS. 1987. Statistical analysis system .Release 6.03.SAS institute. Ine., carry, NC,USA.

16. Singh, S., C.S. Riar and Saxena. 2008. "Effect of incorporating sweet potato flour to wheat flour on the quality characteristics of cookies." African journal of food science 2:065072.

17. Van Jaarsveld $P J$, Faber $M$, Tanumihardjo $S A$, Nestel $P$, Lombard $C J$, Benadé AJS. 2005. $\beta$-carotene-rich orange-fleshed sweet potato improves the vitamin $A$ status of primary school children assessed with the modified-relative-doseresponse test. Am. J. Clin. Nutr., 81: 1080-1087.

18. Van Hal M. 2000. Quality of sweet potato flour during processing and storage. Food Rev. Inter. 16: 1-37.

19. Woolfe JA. 1992. Sweet potato: An Untapped Food Resource. Cambridge University Press, Cambridge, 292-389. 


\section{الخواص الكيميائية و الفيزيائية والحسية لكيك البطاطا}

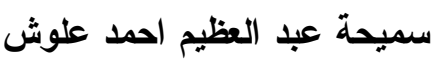

وحدة بحوث المطبخ التجريبى- معهل بحوث تكنولوجيا الاغدية - مركز البحوث الزراعية - جيز ة- مصر

تعتبر البطاطا من الاغدية دات القيمة الغذائية العالية، لبس فقط لما تحتوية من السكريات

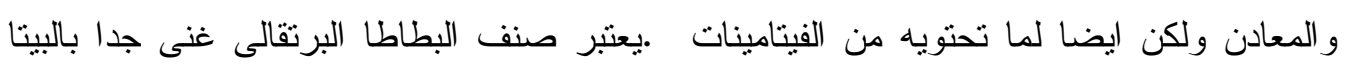

كاروتين و مصدرمن المصادر الرخيصة لفيتامين ا.

فى هده الدراسة تم تدعيم الكيك بنسب مختلفة من دقيق البطاطا البرتقالى و الابيض بنسب

مختلفة و هى • او • rو •r بالمائة و يعتبر دقيق البطاطا بمثابة مصدر للطاقة و المو اد الغذائية الهامة

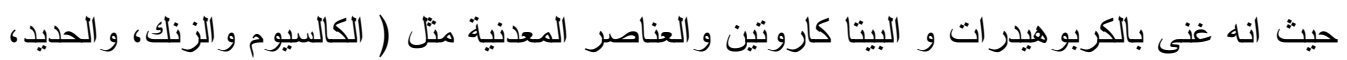

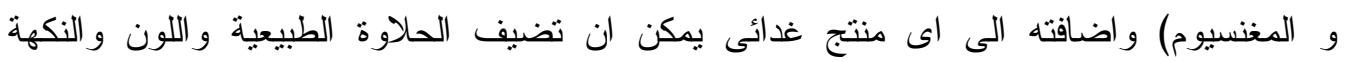

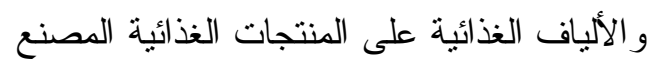

تم عمل تقييم كيميائيا وفيزيائي لكل نوع من انواع الكيلك المدعم بالبطاطا ونم تقدير الطاقة الكلية

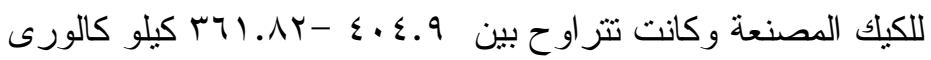

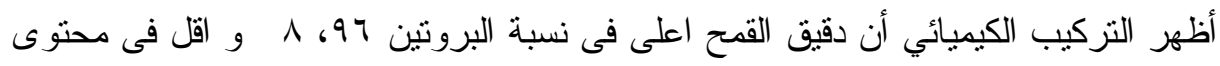

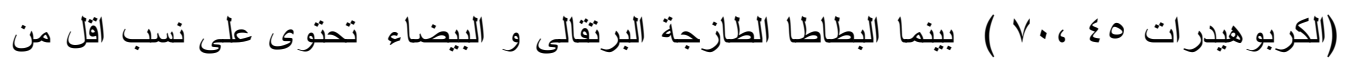

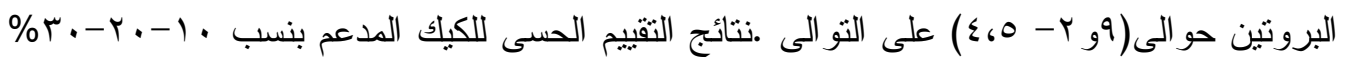

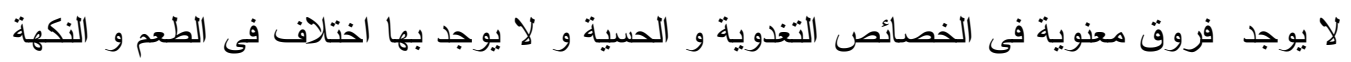

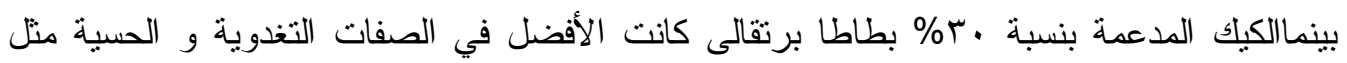
الزيادة في الحجم، و الليونة و القبول و زادت مدة الصلاحية . ب يوما مع التخزين بالتبريد 